\title{
Pojem komplexity v díle Teilharda de Chardin ${ }^{1}$
}

\section{The Concept of Complexity in the Work of Teilhard de Chardin}

\author{
Františka Jirousová \\ Ústav filosofie a religionistiky \\ Filozofická fakulta Univerzity Karlovy v Praze \\ Nám. J. Palacha 2; 116 38, Praha 1 \\ frantiska.j@centrum.cz
}

\begin{abstract}
Abstrakt/Abstract
Záměrem textu je vyložit pojem komplexity v křest’anské evoluční teorii Teilharda de Chardin. V úvodu je nastíněna Teilhardova metoda pracující s hodnotovým aspektem a rozlišující tři kvality bytí (jednotu, různorodost a intenzitu vztahů), které v evoluci narůstají. Hlavní část článku tvoří pokus o nalezení kritéria komplexity různých celků a organismů na základě těchto tří kvalitativních aspektů. V závěru textu je načrtnuto hlavní teologické téma Teilhardovy teorie: Bohem stanoveným cílem evoluce založené na sebeorganizaci je umožnit kreativitu a svobodu na každé z evolučních rovin, a to v míře podle dosaženého stupně komplexity. Na úrovni noosféry dosahuje svoboda své plnosti a starost o pokračování evoluce, včetně nalezení vlastního jedinečného příspěvku do komplexních celků lidských společenství, se stává vlastním úkolem člověka jako spolupracovníka na tvoření světa.
\end{abstract}

The paper presents the concept of complexity in the Christian evolutionary theory of Teilhard de Chardin. First, the Teilhard's method is presented, dealing with values and distinguishing three qualities of being (unity, diversity and intensity of relationships) which increase in the evolution. Author then attempts to find criteria of complexity of different systems and living entities, based on the three mentioned qualities. Finally, the main theological topic of Teilhard's theory is sketched: Evolution is based on self-organization and its goal (determined by God) is to enable creativity and freedom at each evolutionary level according to the level of attained complexity. At the level of noosphere, freedom reaches its fullness; the concern of human being as a co-worker on creation of the world with advancing evolution becomes his main task, including the search for one's own unique contribution to the complexity of the human systems.

Pierre Teilhard de Chardin (1881-1955) byl jezuitský kněz, paleontolog a filozof. Z filozofického hlediska bylo jeho cílem vytvořit teorii, která by se zabývala postavením člověka v evolučním vesmíru a odpovídala na otázku po smyslu a cíli lidského jednání.

\footnotetext{
${ }^{1}$ Článek vznikl v rámci projektu „Opomíjené stránky v díle Teilharda de Chardin“ (č. 165515) realizovaném na Filozofické fakultě v Praze 2015 a podpořeném Grantovou agenturou UK.
} 
Z hlediska křest'anského to znamená vytvořit křest'anskou teorii evoluce, tzn. propojit chápání dějin jako cesty k plnosti bytí v Bohu (pléroma) s evolučním pohledem na svět.

Pojem evoluce používá Teilhard pro vývoj všech forem bytí, které mají schopnost vytvářet komplexní systémy, tedy spojovat se nebo být spojovány do organizovaného celku na základě určitých vazeb. Evoluce se proto vztahuje na celé dějiny vesmíru od vzniku prvních galaxií, slunečních soustav a vytváření Země, zahrnuje dále dějiny celé biosféry a v současnosti se odehrává ve vývoji lidských společenství. Pojem evoluce může být v Teilhardově teorii vztažen také na vývoj individua.

K Teilhardovu dílu existuje velké množství komentářů. Všechny se shodují na tom, že hlavním termínem teorie je komplexita (complexité), o které Teilhard tvrdí, že v průběhu evoluce narůstá nebo by od roviny člověka, tzv. noosféry, alespoň narůstat měla, protože jde o vlastní lidský úkol. O to pozoruhodnější je, že téměř žádný z komentářù se nepokouší tento termín jakkoli blíže vyložit. Jedno z mála bližších vymezení, ve své stručnosti poměrně výstižné, ale málo vysvětlující, lze nalézt v D’Quinceho pojednání, kde charakterizuje teilhardovské pojetí takto:

„Látka vesmíru projevuje vnitřní organizační sílu, která má tendenci seskupovat částice, ze kterých se skládá, aby z nich takto formovala stále více rozrůzněné a stále více sjednocené celky. “2

Vymezení obsahuje tři podstatné znaky komplexních systémů: (1) Vznikají samouspořádáním neboli samoorganizací (zde jako pouvoir interne) a jsou to celky (2) diferencované a zároveň (3) propojené. V tomto článku se zaměřím výlučně na podrobný výklad samotného termínu komplexita s ohledem na tři výše zmíněné znaky. K tomu nejdříve nastíním obecné pojmové schéma Teilhardovy teorie. Takto objasněné pojmy pak budou použity ve druhé a třetí části při vymezení základních znaků komplexních systémů jak co do obecného typu, tak i z hlediska individuí. Poslední část bude věnována souvislosti komplexity a samoorganizace $\mathrm{v}$ teologickém kontextu Teilhardovy teorie. Cílem článku je ukázat, že Teilhardův termín „komplexita“ může být zajímavý i pro současnou filozofii a debaty týkající se vývoje lidského společenství.

Co se týká Teilhardovy metody, jež je velmi často kritizována jako amatérské směšování pojmů, uvedu zde jen stručnou poznámku. ${ }^{3}$ Teilhardova metoda je blízce př́buzná př́ístupu např. obecné teorie systémů nebo holismu. Základem těchto přístupů ke skutečnosti je přesvědčení, že svět vykazuje určitou jednotu, není roztržen do několika nijak se neovlivňujících oblastí, protože na každé rovině lze nalézt něco, co je společné rovinám všem a co lze také pojmově zachytit. Tímto sjednocujícím fenoménem jsou vztahy: „Společné tematické jádro vztahů se zdá být přítomné na každé

\footnotetext{
${ }^{2}$ D’Ouince (1970, s. 53). Pokud odkazuji na francouzský originál, je překlad vlastní.

${ }^{3}$ Z novějších textů srovnej Salmon (2010, s. 175-186).
} 
úrovni.““4 Právě zaměření na vztahy mezi různými částmi celků nebo různými celky navzájem a jejich teoretický popis je to, co určuje hlavní znak Teilhardova myšlení.

Teilhardova teorie hledá zákony, které působí na všech rovinách evoluce. Jeden z interpretů vykládajících metodu této teorie uvádí, že Teilhard hledá

„,zákony“ evolučního růstu, které mohou být ,viděny“ jako platné při vývoji

lidských společenství, života rostlin i zviŕrat, a rovněž v oblasti atomární a subatomární hmoty“. 5

To v žádném případě neznamená, že neexistují speciální zákony, které popisují pravidelné vztahy mezi příčinou a účinkem např. pouze v biosfére nebo oblasti fyziky, a kterými proto nelze vysvětlovat děje na jiných rovinách, podobně jako nelze přenášet mnohé speciální pojmy napříc různými rovinami popisu.

Univerzální pojmy celé teorie musejí mít ovšem stejné významové jádro, at' se vztahují k popisu interakce molekul, nebo chování skupiny lidí, nakolik jde právě o obecné ontologické pojmy. Pro tento typ pojmů si Teilhard s oblibou vybírá zavedené termíny z prrírodních věd s již ustáleným významem (jako např. energie), přičemž je ale rozčlení do několika typů pro každou rovinu evoluce, nicméně se společným významovým jádrem, což naráží na nepochopení zástupců vědních oblastí, jejichž pojmy Teilhard takto ,zneužil“. Nebo naopak použije pojem filozofický (vědomí) či teologický (duše) k vyjádření podstaty nějakého jevu na rovině fyzikální či biologické, což vyvolává podobné reakce.

Teilhardovy pojmy tedy nejsou analogie ani metafory, jsou to speciální pojmy „šité na míru“ jeho teorii. Ta je založena na hypotéze (v Teilhardově díle mnohokrát deklarované včetně výkladu samotného pojetí vědecké hypotézy jako ,nejvyššího duchovního činu, díky němuž prach zkušenosti nabývá tvar"6), že bytí má určité kvalitativní stupně. Evoluce je podle Teilharda proces nedokončený a bytí není z toho důvodu rozvinuto do své plnosti. Hlubina, kvalita, intenzita či „objem“ bytí, lze-li to tak říci, se v evoluci prohlubuje nebo by se alespoň prohlubovat měla, protože tento proces není minimálně od lidské roviny automatický. Je to právě myšlenka stupňů a kvalit bytí, kterou se Teilhardova filozofie vylučuje z teorií, jež byly od vzniku novověké přrírodovědy uznávány za vědecké. V nich nelze o žádných stupních bytí uvažovat, a $\mathrm{z}$ toho důvodu také klasická prrírodověda (např. neodarwinismus) popírá, že v evoluci cokoli „,narůstá“, včetně komplexity.

\footnotetext{
${ }^{4}$ Berrien (1968, s. 6).

${ }^{5}$ O'Connell (1982, s. 83).

${ }^{6}$ Teilhard (1957, s. 289).
} 
V tomto článku se pokusím Teilhardovo zacházení s pojmy a některé aspekty nauky o nedokončeném bytí ukázat právě (a nutně jen částečně) na jeho pojmu komplexity, který je také hlavním ze sady všech univerzálních pojmů jeho teorie.

\section{Obecné schéma}

Celek své evoluční nauky nazval Teilhard teorií tvořivého sjednocení (union creatrice) a tvoření definuje takto: „Tvořit znamená sjednocovat.“7 Tato definice se vztahuje také na tvoření božské: „Tvořit v režimu konvergentní kosmogeneze znamená pro Boha

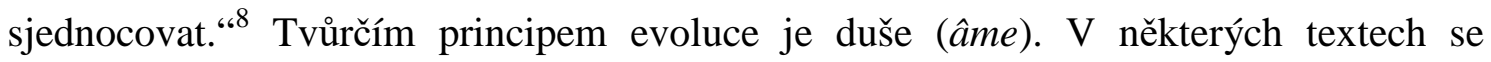
Teilhard tomuto pojmu vyhýbá a používá jako synonymum termín „duch“ (esprit). To souvisí se zákazem publikace teologických a filozofických pojednání uvaleným na Teilharda jeho nadřízenými ${ }^{9}$, což se výrazně odrazilo také v terminologii jeho esejů. Na základě Teilhardových dopisů ${ }^{10}$ lze dokázat, že kvưli (marné) naději na publikaci deklaroval některé spisy jako vědecká pojednání a podobným termínům se v nich vyhýbal, naproti tomu v textech před rokem 1925, kdy začala cenzura jeho díla, a později v „soukromých“ (tajných a cyklostylovaných) textech teologických užívá pojem běžně.

Ducha vymezuje Teilhard jako „schopnost syntézy a organizace““. ${ }^{11}$ Totéž platí i pro aktivitu duše (v textu budu nadále používat pouze tento termín), která umožňuje existenci nejrůznějších vazeb a relací mezi různými druhy evolučních celků i uvnitř nich. Spojení obecně znamená vztah, ve kterém dvě či více duší mezi sebou sdílí nebo vyměňují určité zdroje - energii, informaci nebo hmotu. Podstatou aktivity duše je shromažd'ování mnohosti nejrůznějšího typu kolem společného středu. Tuto aktivitu nazývá Teilhard centrování ${ }^{12}$ nebo jen sjednocování či syntéza.

„Pro části seskupené duší v jednom těle (a tím pozvednuté $\mathrm{k}$ vyššímu stupni bytí) ,být více znamená být více sjednocen s mnohými‘. Pro samotnou duši, princip jednoty, ,být více znamená více sjednocovat mnohé‘، ‘13

\footnotetext{
${ }^{7}$ Teilhard (1973, s. 211).

${ }_{8}$ Teilhard (1963, s. 271).

9 Hlavním důvodem represí (včetně zákazu vyučování v Paříži) byla Teilhardova snaha revidovat křest’anské pojetí tzv. dědičného hříchu v rámci evolučního pohledu na vesmír. K tomu srovnej cit. dílo R. D’Ouince a článek D. W. Viney (2010): „Teilhard: Le philosophie malgré l'église“" [anglicky].

${ }^{10}$ Téma je podrobně (včetně ukázek z dopisů) vyloženo v připravované dizertační práci autorky.

${ }^{11}$ Teilhard (1990, s. 216).

12 „Centrologie“ je také název Teilhardova hlavního systematického eseje (Teilhard 1963, s. 104-134).

${ }^{13}$ Teilhard (1965b, s. 73).
} 
Teilhard často mluví o organizaci mnohosti, v čem ale konkrétně spočívá organizační činnost duše, už blíže nevysvětluje. Navrhuji chápat ji především jako vytváření forem a struktur v nejširším smyslu slova. Každý typ mnohosti organizovaný kolem společného centra potřebuje formu, která zajišt'uje jednotu částí v celku, tedy spojení pomocí vztahů při společném sdílení různých zdrojů. Formu lze vymezit jako soubor pravidel. Za pravidlo zde budu považovat v nejširším smyslu slova cokoli, co vytváŕí prostor pro sdílení a $\mathrm{v}$ tomto prostoru usměrňuje způsob sdílení zdrojů mezi různými částmi jednoho celku nebo mezi různými celky navzájem. Primárním účelem pravidel a forem je v Teilhardově teorii umožňovat různé typy aktivit a jasně vymezených vztahů, nikoli omezovat. V závěru bude vše upřesněno při úvaze o samouspořádání.

Podobně jako každá organizační sjednocující činnost potřebuje nějaké ohnisko, centrum, odkud aktivita formování vychází, tak také každá duše musí mít nějaké ohnisko své aktivity. Toto ohnisko, které Teilhard nazývá vědomí, může nabývat různých podob, z nichž lidské sebevědomí je dosud jeho nejvyšší formou, ale v žádném prípadě jedinou.

Teilhard nazývá činnost vědomí syntézou. Základní syntetickou funkci všech typů vědomí budu interpretovat jako schopnost zajišt'ovat jednotu celku tím, že vztahuje sjednocovanou mnohost ke společnému centru (ohnisku) a to tak, že všem spojeným různým částem zprostř̌edkovává něco, co je zároveň a jako totéž přítomno v každé různé části sjednocovaného systému. Jestliže duše v základě pracuje pomocí nějakého vlnění, jak lze Teilhardovo pojetí interpretovat (používá spíše slovo vibrace ${ }^{14}$ ), tak tím, že tatáž vibrace rozechvívá s určitou intenzitou různé části celku, zajištujuje jednoduchou prostorovou i časovou informaci a pravidla, na základě kterých se spojená mnohost může orientovat směrem $\mathrm{k}$ centru.

Obecně lze tedy formující aktivitu duše chápat jako synchronizaci mnohosti za pomoci dvou hlavních typů činnosti: Za prvé sdělování společné formy všem částem, za druhé sdělování zprávy o společném ohnisku (vědomí) sjednocovaného celku. Obojí typ aktivity nabývá různých podob podle stupně komplexity systému, ale v jeho základu leží vždy totéž: strukturace času a prostoru, kterou lze explikovat pomocí pravidel, a sdělování společného ohniska všem sjednocovaným částem. Teilhardovo dílo poskytuje možnost, jak blíže uvažovat o podobách nereflektivních vědomí, různých typů center (duší) a různých způsobů organizace pomocí různých typů vlnění či vibrace, ale to by překračovalo rámec této studie. ${ }^{15}$

Hlavním zákonem Teilhardovy teorie je Zákon diferencující jednoty, podle kterého je to právě určité sjednocení, vztah, díky kterému se prohlubuje odlišnost v

\footnotetext{
${ }^{14}$ Srovnej Teilhard (1973).

${ }^{15}$ Téma je vyloženo v několika kapitolách připravované dizertace autorky.
} 
evolučním procesu zúčastněných prvků, a tím také stupeň jejich bytí, protože hlavní kvalitou evoluce je pro Teilharda různorodost.

„Univerzum se projevuje jako neustálý proces diferenciace (,personalizace'), - tato diferenciace elementů je spjata s jejich postupným sjednocováním (,jednota diferencuje`)،"16

Zákon tedy tvrdí přímou úměru mezi stupněm spojení, syntézy, a mírou diferenciace spojených částí. Tento zákon se podle Teilharda projevuje na všech evolučních rovinách a obecně odpovídá na otázku, jak vznikají různé typy bytí. Podrobným rozepsáním evolučních fází by bylo možné ukázat jeho procesní stránku, ve které se střídají fáze divergence (rozrůzňování), konvergence (spojování) a emergence (vynoření se nového), vždy je to však nějaký typ vztahu - spojení, lišící se podle konkrétní fáze, který leží v základu utváření různorodosti. (Takový výklad nabízí Teilhard v knihách Vesmír a lidstvo a Místo člověka v prírodě.)

Zákon diferencující jednoty říká, že když se tytéž části spojí do různě velkých celků, vlastnosti takto vzniklých celků se budou lišit a zároveň se mohou výrazně proměnit vlastnosti takto spojených částí. Obecně lze říci, že je to struktura, forma a organizace vazeb, tedy syntetická činnost duše, která je prŕíčinou diferenciace. Zákon ale v žádném případě netvrdí, že jakékoli spojení diferencuje. Když naházíme na hromadu stejné prvky, nezačnou se automaticky spojovat a diferencovat. Podmínkou rozrůznění je právě společná forma celku a společné sdílení různých zdrojů. Kromě toho vzniká v evoluci mnoho typů vztahů a forem, které své části spíše omezují, zestejňují to, co bylo předtím různé, nebo dokonce své prvky ničí. $\mathrm{K}$ této otázce, která přímo souvisí se zkoumáním kritéria komplexity, se vrátím až v závěru.

Formující činností se aktivita duše nevyčerpává, spíše je pouze prostředkem k určitému cíli. V Teilhardově díle je duše především principem nesmrtelnosti, což znamená, že díky své schopnosti organizace utváří v každém komplexním systému jakési nesmrtelné jádro, které se po smrti „,vyloupne“ a zapojí pod vliv nejvyšší centrující duše vesmíru - Krista, v křest’anství druhé božské osoby, nazývaném v Teilhardově díle různými způsoby, např. „forma světa“, Forma mundi, „,centrum všech center “17, nejčastěji však bod Omega ${ }^{18}$. Utváření nesmrtelného jádra duše pod jeho vlivem je ovšem rozsáhlé téma, které zde budu vykládat pouze nepřímo $\mathrm{v}$ souvislosti se samoorganizací komplexních systémů.

Ve svém základu vyjadřuje zákon diferenciace spojením myšlenku, že rozvoj kvalit a stupňů bytí probíhá od nesjednocené mnohosti nesmírného počtu téměř

\footnotetext{
${ }^{16}$ Teilhard (1988, s. 112).

${ }^{17}$ Teilhard (1965, s. 392) a Teilhard (1962, s. 86).

${ }^{18}$ Teilhard (1965b, s. 82-84).
} 
totožných částic, případně částic několika základních typů, ke stále menšímu počtu propojených komplexních systémů, jejichž části se od sebe navzájem stále více odlišují. Zároveň s jejich diferenciací narůstá automaticky také síla jejich vědomí a vnitřní psychická stránka. Celý tento proces postupného formování a diferenciace spojené s prohlubováním psychiky se nazývá zkomplexňování neboli konvergentní kosmogeneze.

Stav maximální diverzity (různorodosti) a zároveň propojenosti (jednoty) všech systémů je podle Teilharda také znakem konečného žádoucího stavu evoluce a pojmenováním pro maximální stupeň komplexity. Také pro tento stav dokončeného vývoje používá Teilhard termín bod Omega, označující tentokrát okamžik v čase, kdy se dokončené stvoření ve své maximální diverzitě a propojenosti plně sjednotí se svým stvořitelem pod společnou formou $\mathrm{v}$ jednom harmonickém systému. Hlavní úlohu $\mathrm{v}$ tomto procesu přisuzuje Teilhard postupně se rozvíjejícímu vědomí a jeho formující aktivitě.

„Protože časoprostor obsahuje a rodí vědomí, musí mít nutně konvergentní povahu. Proto se jeho nesmírné rozlohy, sledovány správným směrem, musí někde vpředu soustřed'ovat do jednoho bodu - bodu Omega - který je spojuje a integruje v sobě. “19

Dokončit evoluci je podle Teilhardovy teorie úkolem člověka, přičemž nejdůležitějším problémem je právě pochopení organizační činnosti, významu forem a pravidel pro sjednocování. Aby bylo možné zjistit, zda se organizační činnost daří či nedaří, je nutné mít nějaké kritérium, podle kterého by bylo možné posoudit, zda komplexita určitého celku narůstá a zda tedy evoluce postupuje správným směrem. Cílem tohoto článku je pokusit se takové kritérium nabídnout.

\section{Obecné kritérium komplexity $\mathrm{z}$ hlediska jednoty}

V informační teorii a př́ibuzných vědních oblastech se dnes používá definice, kterou lze formulovat například takto: „Komplexita objektu je velikost nejmenšího počítačového programu potřebného k jeho generování.“20 Jediný článek na téma Teilhardova pojetí komplexity se pokouší jeho pojem přiřadit $\mathrm{k}$ tomu $\mathrm{z}$ informatiky a navrhuje, aby za kritérium komplexnosti byla vzata složitost DNA, která je prý v případě člověka nejvyšší. $^{21}$ Také jednoduchá webová definice vymezuje komplexitu jako „míru složitosti“ nějakého systému.

Se ztotožněním komplexity a složitosti lze ale těžko souhlasit. V Teilhardově teorii je nejprve jisté, že komplexita neznamená složitost ve smyslu komplikovanosti

\footnotetext{
${ }^{19}$ Teilhard (1990, s. 216).

${ }^{20}$ Gleick (2011, s. 337).

${ }^{21}$ Walter (1969, s. 136-148).
} 
systému s neschůdnou komunikací. Komplexita je především něco, co by mělo v průběhu vývoje narůstat, aby evoluce mohla pokračovat, a to složitost v tomto smyslu rozhodně není. Ohledně DNA je problém už v tom, že genetickou informaci mají pouze biologické systémy, které tvoří v množině komplexních systémů - kam patří např̀. také jazyky, umělecká díla nebo instituce - jen zlomek. DNA se zdá být spíše zápisem některých „pravidel stavby“ komplexního systému, který musí být interpretován nadřazenou jednotkou, tedy duší. Z délky zápisu pravidel lze velmi těžko usuzovat na kvalitu stavby, která se podle něj vytvoří, podobně jako délka knihy nic neříká o její komplexitě, ani složitost zákonů nevypovídá o kvalitě vztahů ve státě apod.

V Teilhardově pojetí se komplexita týká především kvality vztahů v systému. Pro návrh měřítka této kvality zkusím využít tři aspekty činnosti duše neboli tři kvalitativní aspekty bytí. Zatím z nich byly zmíněny pouze dva: zaměření na jednotu a na diferenciaci zároveň. Třetím je intenzita vztahů.

Ve světě se podle Teilharda vyskytuje několik různých typů spojení částí do nějakého celku, ne všechny ale můžeme nazývat komplexním systémem, protože některé celky, ačkoli jsou složené z částí a mají určitý objem a hmotnost, jsou pouhé agregáty. Teilhard vymezuje agregát jako „prosté shlukování, to jest jakékoli nahromadění neuspořádaných částic“. ${ }^{22}$ Základním znakem k rozpoznání neuspořádaného agregátu je chybějící vzájemná provázanost (uspořádanost, organizace) částic a z toho plynoucí pravděpodobnost, že libovolný prvek nalezneme na libovolném místě.

Teilhard používá jako synonymum komplexity často „navíjení“ (enroulement), což je př́ibuzné etymologii tohoto termínu. Latinské complexio znamená „spojení“, „objetí“, complexus lze přeložit jako „sepětí“ a etymologicky pochází od com-plector, „se-tkat“, „s-plést““. ${ }^{23}$ Komplexitu je nejjednodušším způsobem možné vymezit jako sdružení „dvou nebo více komponent, které jsou spojeny takovým způsobem, že je těžké je oddělit.“24 To neznamená, že by byly těžko oddělitelné mechanickým způsobem nebo by jejich vazby byly nějak zvlášt' pevné, ale že po rozdělení ztrácejí svoji funkci. V Teilhardově terminologii ztrácejí ty diferencující vlastnosti, které byly umožněny právě spojením na základě zákona diferencující jednoty.

Komplexní systém označuje celek, jehož vlastnosti jsou jednak závislé na částech, ze kterých se skládá, a který zároveň vlastnosti svých částí určitým způsobem ovlivňuje, což se v Teilhardově teorii vztahuje k působení formy a jejímu diferencujícímu účinku. Existuje tedy dvojí závislost typická pro komplexní systém: Vlastnosti celku nelze

\footnotetext{
${ }^{22}$ Teilhard (1993, s. 15).

${ }^{23}$ Za etymologické postřehy děkuji jednomu z anonymních recenzentů (stejně jako za všechna další laskavá vylepšení článku).

${ }^{24}$ Srovnej Heylighen (1996).
} 
zjistit jeho rozložením na části, což se vyjadřuje známou holistickou zásadou: Celek je více než suma jeho částí. Zároveň také platí, že funkce a vlastnosti části se mohou plně projevit pouze v určitém celku, se kterým je část spojena.

Pro ilustraci lze najít nesčetné množství příkladů. Oddělením některého orgánu z lidského těla ztrácí tento svoji funkci a pochopitelně je ovlivněna či zaniká i funkce zbylých částí, pokud není možné ztracený orgán nahradit. Rozdělením molekuly vody na vodík a kyslík zanikají chemické vlastnosti typické pro vodu a vznikají dva nové prvky s vlastnostmi chemicky odlišnými. Komplexní systém tvoří také Země a Slunce. Život na Zemi je závislý na slunečním záření a se zánikem Slunce nutně zanikne také veškerý pozemský život.

Spoustu obdobných prríkladů lze nalézt i na rovině lidských společenství, které nemají charakter náhodného uskupení. Rozbitím funkční rodiny se mění povaha a role členů, kteři ji dosud tvořili, a zaniká nebo se podstatně mění vlastnost ,plnit funkci rodiny“, která náleží celku, nikoli jeho částem. Proto nelze např́íklad náhodně srocený dav lidí nazvat komplexním systémem, protože zde neexistují žádné pevné vazby, které by ovlivňovaly vlastnosti jednotlivých členů, a po rozdělení takové neprovázané skupiny se také nezmění jejich vlastnosti. Ve skutečném komplexním systému může naopak za určitých okolností i nepatrná změna v jedné části mít značný vliv na celý systém.

Pokud bychom měli zvolit nějaké základní kritérium komplexního celku z hlediska jeho jednoty, byla by to právě schopnost jednat jako jeden celek, tedy sjednocený systém, která agregátu chybí. V případě člověka zajišt’uje tuto schopnost vůle, která zaměřuje celek organismu $\mathrm{k}$ určitému cíli, přičemž jeho realizace je závislá na tom, zda všechny části vhodně spolupracují. Případy, kdy se člověk nemůže rozhodnout a je tím doslova tělesně paralyzován, poukazují právě na to, že člověk je komplexním celkem, ve kterém se složky musí na směru, který předepisuje vůle, určitým způsobem „,dohodnout“ a dát se do pohybu všechny najednou. Na úrovni biosféry by se patrně také dala najít analogie vůle, např́iklad v podobě instinktu, který aktivuje organismus jako celek. Také na rovině geosféry můžeme usuzovat, že například krystal, který se kutálí z kopce, bude komplexním systémem, kdežto zvětralá, rozdrobená hornina už ne. Hranice komplexního celku končí tam, kde končí tato vzájemná závislost složek neboli jejich „centrovanost jednání“ ${ }^{25}$ V př́ípadě lidských skupin nebo institucí posuzujeme jejich jednotu právě podle schopnosti domluvit se na společném cíli a také ho jednotně, tedy bez vnitřních rozbrojů následovat, a to s využitím všech energetických zdrojů, které má skupina $\mathrm{k}$ dispozici. To je v případě systémů „složitých“ ve smyslu komplikovanosti vztahů téměř nemožné nebo alespoň značně ztížené.

${ }^{25}$ O’Manique (1969, s. 30). 
Hlavním znakem, který odlišuje agregát a komplexní systém, je tedy př́tomnost určitých stálých vazeb mezi všemi částmi komplexního celku, které jsou umožněny společnou sjednocující formou. Vazby musí být centrované, což znamená, že každá část musí být pomocí nějaké vazby v kontaktu jak s centrem, tak se všemi ostatními částmi. Díky propracované komunikační síti může být částem sdělován nejen samotný cíl celku, ale i různé informace a jiné zdroje k jeho následování. Což ale neznamená, že zde existují spoje vedoucí od každé části ke každé jiné části, což by bylo z hlediska komunikace patrně velmi neefektivní. ${ }^{26}$ Efektivita znamená, že informace či něco, co se dynamickými vazbami přenáší, je přeneseno v co nejkratším čase a za užití co nejmenšího množství energie. Mezi centrem a částmi musí také fungovat dobrá zpětná vazba, tzn. že centrum musí mít zprávu o tom, co se stalo s informacemi či jinými zdroji, které byly k částem vyslány, jak byly využity ke společnému cíli.

Ve vztahu ke sjednocující činnosti duše lze říci, že komplexnější je ten systém, který je schopen sjednotit více mnohosti takovým způsobem, že všechny části jsou schopny jednat jako jeden celek. Ačkoli je takové měřítko pouze kvalitativní, protože nelze exaktně měřit a vyjádřit nějakým číslem, lze na jeho základě nicméně rozhodnout, zda je nějaký systém komplexní nebo ne, a do jisté míry také porovnávat stupeň komplexity u stejných typů systémů. $\mathrm{V}$ případě lidských skupin stejného typu lze např. stanovit, že více komplexní je ta, která dokáže déle a efektivněji (tedy se zapojením všech svých členů a zdrojů) následovat stanovený cíl, případně ho dokonce operativně změnit, vyžádají-li si to okolnosti. Flexibilita ve smyslu stanovování nových cílů, když se staré ukážou neprosaditelné, a především rychlé organizace všech složek systému k následování cíle nového, by patřila k tomuto kritériu.

\section{Obecné kritérium komplexity z hlediska mnohosti}

Z některých Teilhardových výroků by se mohlo zdát, že kritérium komplexity - co se týká posouzení kvality celku zhlediska mnohosti, kterou obsahuje - lze nalézt jednoduše $\mathrm{v}$ počtu částí, které určitý systém zahrnuje. Tento počet narůstá od jednoduchých atomů ke složitým přes jednodušší anorganické molekuly ke složitějším organickým a v živočišné ř́ši od jednobuněčných k mnohobuněčným organismům. V případě atomů by tak narůstající komplexita mohla být vyjádřena Mendělejevovou tabulkou prvků. Aplikováno na živé bytosti se ale toto kritérium stává velmi nešikovné, protože počet částí např́íklad $\mathrm{v}$ organických systémech dosahuje astronomických rozměrů.

Kritérium kvality mnohosti bude tedy vhodné hledat spíše v různosti, variabilitě částí spojených do jednoho celku, jak to také napovídá zákon diferencující jednoty. V textu Místo člověka v př́rodě uvádí Teilhard dva hlavní typy komplexních systémů,

\footnotetext{
${ }^{26}$ Srovnej Johnson (2009).
} 
krystalické struktury a korpuskule, z nichž ty první jsou charakterizovány prostým opakováním určitého motivu a patří sem především různé typy systémů geosféry jako horniny a minerály. ${ }^{27}$

Prvky evolučně pokročilého komplexního systému, korpuskule, musí být naproti tomu v nějakém ohledu různé, jinak se nejedná o pravou komplexitu, la combinaison, jak také Teilhard říká. Tento princip se nazývá porušení symetrie a organické komplexní systémy se jím liší od krystalických struktur. Podle současných poznatků

„může být komplexita charakterizována nedostatkem symetrie nebo ,porušením symetrie', faktem, že žádná část nebo aspekt komplexní entity nemůže poskytnout dostatečnou informaci, aby bylo možné skutečně nebo statisticky předpovědět vlastnosti ostatních částí.“28

To je parafráze holistické zásady o nemožnosti přecházet plynule z nižší úrovně organizace na vyšší, aniž by se muselo projít také změnou pravidel organizace. To znamená, že v universu existují různé typy organizačních úrovní a různé typy prolínajících se struktur. Ze zkoumání pravidel např. na úrovni atomů nelze odvodit, jaká pravidla fungují na úrovni buněk. Ze zkoumání forem organizace buněk zase nelze předpovídat nic konkrétního o formách uspořádání společnosti. Řečeno z hlediska duší: Méně komplexní duše, která je součástí nějakého širšího celku, nemůže na základě svých pravidel odvodit pravidla organizace tohoto nadřazeného celku. Této vlastnosti by se mohlo ř́kat horizontální rozrůznění. Co se nicméně dá obecně tvrdit je to, že na každé úrovni organizace se vyskytuje určitá duše podmiňující strukturu a vztahy sdílení v celku, který jí náleží, a podle Teilharda tam také platí určité zákony, kterým říká obecné evoluční zákony a které vyjadřují pravidla společná všem organizačním úrovním. To je např. právě zákon diferenciace spojením.

V krystalických formách se sice jednotlivé atomy diferencují spojením na základě pravidel krystalové mřížky, přinejmenším co se týká jejich různé polohy v geometrii krystalu, nicméně lze předvídat, že na jiných místech krystalu budou stejné atomy a jejich polohu lze patrně identifikovat na základě určitého vzorce, tedy pravidel organizace krystalu. V živých organismech, jako ve všech vyšších formách komplexity, je diferenciace mnohem hlubší a ze znalosti jednoho specializovaného orgánu proto nelze předpovědět, jaké další orgány se $v$ organismu ještě nacházejí ani kde jsou umístěny.

Na úrovni noosféry nabývá tato asymetrie nejrůznějších podob. Např́íklad ze znalosti chování lidí v jedné rodině, instituci, státu, nelze odvodit chování v dalších rodinách, institucích a státech. Obecně platí, že čím komplexnější systém, tím více

\footnotetext{
${ }^{27}$ Teilhard (1993, s. 15).

${ }^{28}$ Heylighen (1996). K tomu srovnej např. Havel (1995).
} 
horizontálních i vertikálních úrovní a tím více porušení symetrie. Názorně to bývá vidět na formách organizace velkých institucí s mnoha podsložkami, jako je např. univerzita. Většinou jsou nějak symetrické (rozdělené na fakulty, katedry atd.), ale v tak velkých komplexech se zároveň vyskytuje množství výjimek, zvláštních pracovišt', oddělení nebo funkcí, jejichž existenci nelze odvodit z celkového organizačního schématu.

Druhou podstatnou složkou vymezení komplexního systému je tedy větší počet rưzných částí v systému zahrnutých, přičemž čím větší stupeň komplexity, tím častěji se objevuje tzv. porušení symetrie, které znemožňuje najít vzorec opakování různých částí v celku. Komplexnější je proto ten systém, který díky své formě dokáže sjednotit více částí tak, aby jim umožnil se díky tomuto sjednocení co nejvíce rozrůznit při stálém sdílení společné formy a následování společného cíle.

\section{Obecné kritérium komplexity $\mathrm{z}$ hlediska intenzity vztahů}

Při hledání kritéria komplexity z hlediska intenzity či kvality vztahů je možné zkoumat složitý problém nejprve na jednodušším modelu. Vezměme si tedy již zmíněnou Mendělejevovu tabulku prvků. Je uran skutečně komplexnější než vodík? V kontextu Teilhardovy teorie nikoliv. Především všechny atomy mají typově tytéž ,„části“, nebo raději funkce či oblasti, protože představa jakýchsi oddělených částic neodpovídá skutečnosti. Těmito „funkcemi“ atomu jsou proton, neutron a elektron. V každém atomu se nacházejí pouze tyto funkce co do typu. Uran má o 91 elektronů a o 91 protonů více než vodík, ale všechny tyto elektrony a protony jsou stejného typu, je jich pouze větší počet, tedy kvantita částí jednotlivých prvků se liší, kvalitativně se části prvků neliší.

Z hlediska kvality mnohosti, kterou zahrnují, jsou tedy všechny atomy na stejné úrovni, protože všechny obsahují tři různé části. Také hledisko jednoty při rozlišení komplexity nijak nepomůže. Umožní pouze konstatovat, že atomy jsou komplexní, protože drží pohromadě a projevují jako jeden celek nějaké vlastnosti, které po rozbití prvku mizí. Jiná situace ale nastává, podíváme-li se na typy vazeb, kterými se prvky mohou vázat do molekul, tedy pokusíme-li se kvalitu atomů rozlišit z hlediska jejich nadřazených systémů.

Z hlediska vazebných sil budou mezi nejvíce komplexní patřit prvky s nejvyšší „schopností“ vázat k sobě další atomy. Pokud jde o schopnost vazeb, zmiňuje Teilhard nejčastěji uhlík ${ }^{29}$, který je součástí jakékoli organické sloučeniny, tedy má rozhodně nejvyšší schopnost vytvářet komplexní systémy. Dále jsou to kyslík, dusík, síra a fosfor, další součásti organických látek. A patři sem také vodík, z hlediska množství jeho částí nejjednodušší atom, ale z hlediska komplexity nesmírně „,komunikativní“ prvek.

${ }^{29}$ Teilhard (1993, s. 22). 
Nejméně komplexní ve skupině prvků jsou z hlediska vazebných možností samožrejmě inertní plyny (He, $\mathrm{Ne}, \mathrm{Ar}, \mathrm{Kr}, \mathrm{Xe}, \mathrm{Rn})$, neschopné navázat jakoukoli relaci $\mathrm{s}$ jinými druhy atomů. To ovšem neznamená, že by tyto formy systémů byly $\mathrm{v}$ Teilhardově filozofii odsouzeny jako „slepé uličky“ evoluce nebo nějaké nižší formy bytí v pejorativním smyslu. Posuzovány z úrovně stejného typu komplexity, tedy atomů a molekul, jsou inertní plyny skutečně bezcenné. $Z$ hlediska mladší a širší úrovně komplexity, např́íklad noosféry, jsou to nenahraditelné prvky, které umožňují člověku nesčetné formy komunikace a realizaci různých speciálních vztahů. Např́klad noční světelné efekty současných měst, které kromě toho, že umožňují mnoho typů komunikace, dávají městům či stavbám také určitou krásu, jsou možné díky neonu; helium jako náplň balonů má zásluhu na mnoha svátečních radostech člověka; radon nalezl použití v přístrojích na předpověd' zemětřesení a také ve zdravotnictví, xenon je součástí UV lamp.

V oblasti živočišné řîše nacházíme jedno význačné kritérium pro určení stupně komplexity, které lze také nějakým způsobem měřit, podobně jako lze určit počet částí v jednodušších systémech. Je jím, jak už bylo zmíněno, stupeň vývoje nervové soustavy a objem mozku, což je měřitelná veličina. Závislost stupně komplexity na vývoji nervové soustavy vykládá Teilhard průběžně ve Vesmíru a lidstvu a zmiňuje ho v mnoha dalších esejích $^{30}$. Směrem, který lze vysledovat v evoluci, by pak byl právě tento „trvalý tah živočišných forem směrem ke stále citlivějším a koncentrovanějším typům nervové soustavy““. ${ }^{31} \mathrm{~V}$ případě organismů biosféry je zjevné, že jejich schopnost vazeb narůstá $\mathrm{v}$ přímé úměře k rozvoji nervové soustavy a objemu mozkovny, tedy je alespoň na této úrovni kritériem kvantifikovatelným. Nicméně lze je užít pouze u organismů, které nervovou soustavu mají, a z hlediska filozofické systematizace není úplně vhodné, protože činí čtenáře závislého na informacích, které si může jen těžko ověřit.

V Teilhardových textech lze ale nalézt ještě další vymezení komplexity, které lze užít jako měřítko jejího stupně ve všech sférách evoluce, nikoli pouze v oblasti biosféry. Komplexita se může zvětšit výhradně nějakým typem spojení, vztahem s jinými celky, při kterém dochází ke sdílení určitých zdrojů. V Teilhardových textech lze najít dvě podobná vymezení komplexity ${ }^{32}$, která se $\mathrm{v}$ žádných komentářích kupodivu necitují, $\mathrm{z}$ nichž to $\mathrm{v}$ eseji Vie et Planètes z roku 1945 je přesnější, takže ho lze považovat za definici.

Podle tohoto vymezení komplexitu neurčuje

\footnotetext{
${ }^{30}$ Např. Teilhard (1993, s. 36).

${ }^{31}$ Teilhard (1959, s. 89).

${ }^{32}$ Teilhard (1957, s. 313).
} 
„pouze počet a různorodost elementů zahrnutých v každém [zkoumaném] případu, ale přinejmenším stejně tak počet a související různorodost vazebných spojení mezi těmito elementy. “33

Teilhard toto vymezení už blíže nerozpracoval a v jiném eseji zase říká, že počet elementů a vztahů v biologických systémech je tak vysoký, že jej nelze nijak spočítat. ${ }^{34}$ Nicméně nemusíme vůbec uvažovat o počtu konkrétních částí či počtu konkrétních vztahů, ale zaměřit se na jejich typy, které lze klasifikovat, a tedy i spočítat podle toho, co je jejich prostřednictvím možné sdílet a jakými prostředky takové sdílení probíhá.

Takto vymezené kritérium také odpovídá tomu, co Teilhard v jiných esejích nazývá šíře životního prostoru. Komplexnější systém disponuje větším počtem různých typů vazeb, kterými spojuje jednak své části, ale především se jimi vztahuje ke svému okolí - má tedy širší pole komunikačních aktivit, byt' třeba pouze v možnosti, vazby nemusejí být nutně vždy aktivní. „Čím je něco v přírodě živější, tím to také rozšiřuje svůj životní prostor.“35 Komplexnější systém má „„širší pole aktivity.“36 Nebo obdobně vyjádřeno ve vztahu k centrující činnosti duše: „Vyšší prvky se dají vždy poznat podle většího poloměru volby, který vychází $\mathrm{z}$ lépe vymezeného středu koordinace a vědomí. “37

Z hlediska intenzity a kvality vazeb jsou relace komplexnějších systémů, ačkoli křehčí, tedy snadněji porušitelné než vazby např. atomů, v jistém ohledu mnohem silnější v tom smyslu, že dokážou sdílet či přenášet nesrovnatelně větší objem informací, hmoty či energií. Atom neumí přenést a sdílet molekulu, kdežto molekula atom ano. Čidla rostlin se nemohou rovnat vynikajícím smyslům zvířat. Zvirire může bud' létat, plavat nebo chodit po zemi, člověk je schopen všech těchto aktivit. Co se týká množství typů vazeb, je člověk jako př́slušník druhu homo sapiens jednoznačně dosud nejkomplexnějším systémem, a to z hlediska všech tří evolučních sfér, nejen biosféry. Variabilita komunikačních cest a objem sdílených zdrojů - kam patři nejen různé materiály a energie, ale $\mathrm{v}$ případě noosféry především informace včetně např́íklad uměleckých výtvorů - a z toho plynoucí schopnost vytvářet širší komplexní systémy v podobě nejrůznějších společenských seskupení, politických a kulturních organizací, mnohonásobně převyšuje objem komunikace v živočišné říši.

Námitka, že říše bakterií co do objemu komunikačních aktivit (např. výměna částí DNA) překonává noosféru, neobstojí, protože jde právě o to, co se sdílí, tedy o různost

\footnotetext{
${ }^{33}$ Teilhard (1959, s. 137).

${ }^{34}$ Teilhard (1993, s. 16).

${ }^{35}$ Teilhard (1993, s. 152).

${ }^{36}$ Teilhard (1959, s. 380) a Teilhard (1963, s. 210).

${ }^{37}$ Teilhard (1990, s. 142).
} 
sdíleného, nikoli o kvantitu. Kromě toho je důležitá také schopnost působit změnu ve stávajících strukturách, což se týká nejen možnosti přetvářet okolní svět, která je u člověka jistě vyšší než u organismů nebo systémů geosféry, ale také o intenzitu působení vazebných sil. Síly formující noosféru, jimiž jsou podle Teilharda hlavně láska, víra nebo intelektuální činnost, mají schopnost zcela proměnit osobnost jedince nebo stávající společenské struktury, což je opět něco, čeho organismus není schopen (radikální změny zde probíhají pouze $\mathrm{v}$ rámci ustálených proměn druhu, např. kukla motýl, a během velmi pomalé evoluce).

Specifičnost vazeb v noosféře je opět téma, které by vystačilo na monografii, zde proto zmíním jen jeden další podstatný znak vazeb vytvářených člověkem: jejich síla je závislá na využití vazeb ze starších evolučních sfér, které dokáže člověk pozměnit pro své účely. Elektřina je upravená vazebná síla geosféry stejně jako všechny typy vlnění, kterými se přenášejí informace. Síla lásky je projev sexuálních sil zesílený a v možných podobách rozhojněný (např. o možnost čistě spirituální lásky) vyšším stupněm komplexity. Teilhard věnoval této vazebné síle včetně její návaznosti na předchozí evoluční roviny mnoho svých textů, nejdůležitější jsou shromážděny ve svazku s názvem L'Energie Humaine (1962).

Shrnuto: Aby bylo možné posoudit komplexitu systému co do jeho obecného typu, je třeba brát $\mathrm{v}$ úvahu všechna tři kritéria $\mathrm{v}$ jejich kombinaci. Za více komplexní nelze považovat celek, který je ve srovnání s nějakým jiným celkem sice schopen jednat jako jeden a následovat cíl, ale jeho prvky vykazují menší různorodost nebo v nich chybí princip porušení symetrie. Zároveň nelze celek složený z mnoha různých částí považovat za komplexní, pokud tyto části, byt' hodně provázané, nejsou schopny společnou koordinovanou činností následovat jeden cíl. A současně nelze považovat za komplexní jednotný a zároveň různorodý celek, který je ale uzavřený vůči okolí, navenek nekomunikuje, je zakonzervovaný ve své neměnné struktuře, nic se svým okolím nesdílí a nepůsobí v něm žádné změny, jeho komplexita proto nemůže žádným způsobem narůstat.

Všechna tři kritéria dohromady měří schopnost centrování, která sestává právě ze současné prrítomnosti všech tří kvalit bytí: Jednoty, mnohosti a šíre životního prostoru, tzn. intenzity vazeb. Pokud by se měla určit společná vlastnost, která označuje jejich kombinaci, byla by to patrně schopnost růstu. Více komplexní je ten celek, který má schopnost růstu vyšší. Správný růst znamená stálé zohledňování všech tři kritérií, na což nelze najít žádný vzorec (tzn. determinovaný vztah mezi př́icinou a účinkem); proto nelze růst zajistit zvnějšku uloženým programem. Pokud narůstá jen jedna z kvalit, může to brzy vést $\mathrm{k}$ rozpadu celého systému, jako např. při neustálém zahrnování rozmanitosti nevyváženém jednotou, tj. provázaností částí. A naopak narůstající provázanost může vést $\mathrm{k}$ potlačení různorodosti. Podobně př́liš intenzivní vztahy 
mohou velmi snadno zničit celek, v němž fungují. Těžko uchopitelný termín „růst“ by měl zohlednit právě nutnost neustálého balancování všech tří kvalit.

\section{Kritérium komplexity $v$ př́ípadě individua}

Výše uvedené trojité kritérium je jen prvním z kroků k určení stupně komplexity a lze ho pro přibližné posouzení aplikovat především na celky skládajících se z částí téhož typu, např́iklad na různé druhy institucí, států, zájmových sdružení apod., tedy na určitou množinu ve srovnání s množinou jinou. Co se týká konkrétních instancí celku určitého typu, je toto kritérium př́liš obecné, protože zatím nezohledňuje aspekt růstu z hlediska jedince. Zkusit najít kritérium pro posouzení komplexity z hlediska konkrétního individua, je v Teilhardově teorii o to důležitější, protože je to pouze lidská duše, jejíž komplexita může růst neomezeně. Je zřejmé, že kritérium použitelné pro individua musí opět zohlednit důraz na kvalitu vztahů, které tvoří základ Teilhardovy teorie, což je totéž jako „šîre životního prostoru“.

Hlavním problémem je, jak určit, co tato šíře vlastně znamená. Je totiž zjevné, že se nejedná o prostorový rozsah fyzické aktivity nebo množství různých činností, protože pak by se specializace musela považovat za něco méně komplexního než různorodost činností. Je ale mnoho lidí, kteří si vybírají činnost, jež je tak úzce specializovaná, že jim samým vůbec sféru aktivit nerožšřuje, dokonce se ani nemusí týkat oblasti mezilidských vztahů. Vědec, který zkoumá vyhynulý druh nebo se velkou část života zabývá řešením jednoho matematického problému. Matka starající se o početnou rodinu, která celý život neopustila místo bydliště. Řemeslník vyrábějící každý den tentýž typ výrobku. Osaměle žijící mnich v klášterní cele. Mnoho lidí, kteří si svobodně zvolili své zaměstnání, může opakovat rutinně jednu činnost každý den a nepotřebují si nijak rozšiřovat životní prostor, např. co do rozsahu pohybu nebo množství různých činností.

Z hlavních tvrzení Teilhardovy teorie plyne, že předmětem posouzení šíře Životního prostoru bude nakonec dosah a šíre organizační, syntetické schopnosti konkrétní duše. Podle Teilharda je podmínkou nárůstu komplexity a tím také úkolem každého, kdo se chce podílet na evoluci, „rozššririt se intelektuálně a emocionálně, až k dimenzím vesmíru““38 Souhrnně nazývá Teilhard tento aspekt „šíre vědomí“ (v podstatě totéž jako šîre duše), což rozhodně neznamená jen šíři intelektuálních zkušeností.

V Teilhardově teorii se nakonec $\mathrm{z}$ hlediska této šíře ukazuje jako nejdůležitější to, co je sdíleno, co koluje mezi různými systémy, je transformováno subsystémy a jako výstup může být užito systémy jinými. Jako východisko pro posouzení šiřre duše a

${ }^{38}$ Teilhard (1965, s. 21). 
vědomí si proto zvolíme určitou „starost o zdroje“. Mezi nejdůležitější zdroje pro utváření lidské společnosti řadí Teilhard to, co se dá sdílet pomocí hlavních typů vazeb na lidské rovině evoluce, jimiž jsou myšlení, víra - v Teilhardově teorii stále spojovaná s vědeckým výzkumem a službou ideálu - a láska, tedy nejrůznější emocionální zdroje, informace, ideje a ideály. Některé z těchto zdrojů lze sdílet i bez vnějšího materiálního nosiče, jako $v$ případě lásky stačí blízkost dvou lidí spojených tímto vztahem a jejich duše se vzájemně organizují a rozšiřují např. prostřednictvím vášně. „Pravá láska existuje jen mezi dvojicí, jejíž vášeň vede oba, jednoho skrze druhého, k plnějšímu vlastnění jejich bytí.“39 Význam lásky, víry, výzkumu a poznání pro pokračování evoluce jsou hlavní témata Teilhardovy etiky a zde je musím nechat stranou. ${ }^{40}$

Širri životního prostoru každého jedince můžeme nejprve posuzovat z hlediska toho, jaký zdroj dodává do celku, jehož je součástí, a jak široký okruh bytostí tento zdroj využívá. Přičemž vůbec není třeba, aby bytosti využívaly tentýž zdroj, v úvahu je třeba vzít právě celou transformační řadu. Transformace je další centrální pojem Teilhardovy teorie a označuje proměny toho, co je sdíleno v průběhu vznikání a existence všech možných relací. Konkrétní jedinec tvoří něco, co využívá dalších sto jedinců, každý z nich to transformuje v různé další typy vazeb, díla či zdroje, které zase využívá a na které reaguje okruh dalších jedinců, o kterých už původce zdroje nemá tušení. Tedy i v př́ípadě zdánlivě zcela drobných činností může být okruh, který je díky vazbám ovlivněn, velmi široký až nepřehlédnutelný. Okolí může ale značně ovlivňovat také pasivita, nekonání. „Zdrojem“, který v tomto prrípadě sdílím svému okolí, jsou právě změny uspořádání okolí způsobené pasivitou, ke kterým by v př́ípadě aktivity nedošlo.

Určité ,prázdno“, které bývá často vnímáno po smrti člověka, ukazuje právě na tuto neviditelnou sít' aktivit a pasivit, která náhle zmizí a tím se zpřetrhá to, co bylo dřive neviditelné, ale co tvořilo základ nějakého celku. V závažnějších případech se po takové události může rozpadnout forma celku. Když zemře matka velké rodiny, která třeba po celý život neopustila domácnost, ale svou činností zajišt'ovala emocionální, intelektuální a materiální zdroje pro všechny, může to mít zásadní vliv na role a vlastnosti členů dosavadní rodiny. Pokud odejde ředitel instituce, která zdánlivě fungovala samočinně, může vyjít najevo, že vlákno funkčních vztahů vytvořené jeho centrující činností bylo utkáno tak precizně, že je těžké ho nahradit, ačkoli se předtím zdálo neviditelné.

Také zdánlivě bezvýznamné aktivity, jako např. úsměv, poctivá řemeslná práce $\mathrm{v}$ detailu, pomoc nabídnutá neznámým člověkem, mohou mít zásadní místo $\mathrm{v}$ retězu př́čin a následků a mohou významně ovlivnit celou transformační sít' zdrojů a vazeb.

\footnotetext{
${ }^{39}$ Teilhard (1962, s. 93).

${ }^{40}$ Tématem se zabývám podrobně v připravované dizertaci, stručněji např. in: Jirousová (2015).
} 
Dosah zdánlivě banálních činností se tak v Teilhardově holistické teorii a etice, která používá pro ukázání významu jednotlivce pro celek právě příklady ze zdánlivě nejobyčejnějších lidských činností, jeví bud' radostně závratný, nebo plný hrozivé zodpovědnosti, záleží na tom, jak se na věc díváme. ${ }^{41}$ Kdo nakonec ví, co bylo poslední kapkou teroristického činu nebo sebevraždy, nebo naopak inspirací vrcholné části symfonie? Třeba právě nějaká taková „drobnost“ jako nenávistné slovo či letmý úsměv milované osoby.

Je tedy zřejmé, že šíře životního prostoru a kvalita vztahů by měla být posuzována podle šíře této komunikační sítě, do které jednotlivý systém posílá zdroj, o který pečuje. A je jisté, že širre chápaná v tomto smyslu může být také v případě úzké specializace velmi rozsáhlá.

\section{Komplexita a samoorganizace}

Otázkou je, jak do kritéria komplexity jedince zapojit ostatní dvě kvality: Jednotu a různorodost. Cestou $\mathrm{k}$ jejich zohlednění je uvažovat o možnosti růstu komplexity, který je podmínkou postupu evoluce. Pokud by nebyl zohledněn růst, mohla by za nejhodnotnější být považována například výrobní činnost nějaké továrny na předměty, které z hlediska Teilhardovy teorie nemají pro rozšiřování komplexity téměř žádný význam, byt' mohou být důležité pro její udržování. O růstu komplexity je možné uvažovat nejvýhodněji v souvislosti s pojmem samouspořádání (auto-arranger), což je jeden z několika Teilhardových termínů pro kreativitu a svobodu v evoluci (další jsou např. autocentrace, auto-centration; samokonvergence, auto-convergence nebo samořídící se, auto-dirigé). Náčrtem výkladu významu tohoto pojmu by měl být alespoň stručně osvětlen také nepominutelný teologický kontext Teilhardovy teorie.

Jako samostatná disciplína $\mathrm{s}$ vlastním předmětem zkoumání byla věda $\mathrm{o}$ komplexitě (complexity science) či teorie komplexity uznána až v 80. letech hlavně zásluhou vědců kolem Santa Fe Institutu. Vzhledem k tomu, že Teilhard jako první použil termín komplexní systém ve stejném významu, jako ho užívá teorie komplexity, včetně jeho neodmyslitelného spojení s jevem samouspořádání (a to již ve 40. letech), je možné ho považovat za jednoho z důležitých iniciátorů této vědní oblasti, ačkoli je jeho dílo mezi současnými př́rodovědci a teoretiky v tomto ohledu naprosto neznámé.

Také hlavní kontext, ve kterém Teilhard uvažuje o vytváření komplexních systémů, je stejný jako v teorii komplexity a je jím soutěž o omezené zdroje.

\footnotetext{
${ }^{41}$ Srovnej Teilhard (1970).
} 
„Podstatou většiny reálných příkladů komplexity je situace, ve které soubor objektů soutěží o nějaký druh omezeného zdroje - např. potravu, prostor, energii, moc nebo bohatství. “42

Teilhardovými slovy: „Pouze pod tlakem (a v závislosti na narůstajícím tlaku) reaguje oživená hmota, aby přežila, tím, že se ultraorganizuje.“43 Termín ultra-organizace označuje vznik nových typů vztahů a forem, které jsou podmínkou pokračující evoluce a ke kterým by nedošlo bez vnějších tlaků, nutnosti vynaložit určité společné úsilí pro získání zdrojů. Jednoduše řečeno: ke spojení s druhými člověka nejčastěji přinutí nějaká nouze a omezenost vlastních sil a možností.

Evoluce v Teilhardově pojetí postupuje právě díky kombinaci nedostatečných zdrojů a sil a touhy po vyšším stupni bytí, v posledku po dosažení jeho plnosti, která je imanentní každému evolučnímu prvku a žádá si ,více moci a více jednat. Ale nakonec a především více jednat a více být “ ${ }^{44}$ Tato vrozená tendence je co do své podstaty všude tatáž, nebot' „vesmírná hmota je oživována absolutním primátem bytí před nicotou“ ${ }^{4}$ podle stupně komplexity systému se ale její působení proměňuje, v biosférée se projevuje jako instinkt přežití a na rovině noosféry ji Teilhard nazývá nejčastěji „,chut' žít“. Právě zde tkví hodnotový aspekt vnořený do samotného středu Teilhardovy teorie, který přírodovědci považují za překročení vědeckých kompetencí, pro Teilharda je ale nutnou součástí metody zkoumání univerza, protože umožňuje uvažovat o stupních a kvalitách bytí.

Tato vrozená touha, kterou Teilhard nazývá také „energií evoluce“, se v základu projevuje jako touha po něčem, co není určitému prvku žádným způsobem známo, má pouze daný směr od nižšího stupně bytí k vyššímu, ale nemůže postupovat jinak než pokusným tápáním (tâtonnement). V situaci omezených či kvalitativně nedostatečných zdrojů není pro naplnění této touhy jiná možnost, než se spojit s ostatními a společně se starat jak o získávání, tak vytváření zdrojů nových, což za určitých podmínek vede automaticky $\mathrm{k}$ diferenciaci, případně vzniku nových typů bytí, a tím také k pokračování evoluce. Jaké jsou to podmínky, může být zodpovězeno právě úvahou o kritériu komplexity, tedy vhodném typu spojení mnohosti do jednoho celku.

Na rovině noosféry jsou projevem touhy „více být“ všechny typy lidské expanze: Touha po moci, bohatství, plození, vědomostech a výzkumu (to je Teilhardovo erbovní téma), uznání, lásce, vztahu s mocnější silou (náboženská touha) - všechny způsoby, kterými člověk může rozšíríit svoji komplexitu. Př́ijemné na Teilhardově díle je, že

\footnotetext{
42 Johnson (2009, s. 4).

${ }^{43}$ Teilhard (1956, s. 219-220).

${ }^{44}$ Teilhard (1990, s. 208).

${ }^{45}$ Teilhard (1963, s. 243).
} 
žádné z nich nekritizuje ani nepovažuje za zcela špatné ani příliš nezdůrazňuje jedny na úkor druhých, naopak ukazuje, že všechny typy lidských tužeb se vzájemně doplňují a mohou mít konstruktivní i destruktivní stránku podle toho, zda komplexitu rozšiřují nebo umenšují.

Jednoduše řečeno: Komplexita roste správným směrem, pokud sleduje obecný cíl evoluce a tím také její pokračování. Podmínkou pokračování evoluce lidského druhu je podle Teilharda sjednocení lidstva pod vedením společného ideálu, společného cíle. Aby byl tento cíl správný, musí být v souladu s obecným cílem celé evoluce, který je stvoření uložen Bohem. Obecným cílem evoluce je plnost bytí (pléroma). Tento cíl se u všech stvořených bytostí projevuje právě jako „slepá“ touha více být.

Pokud by ovšem bylo cílem pouze samotné dosažení plnosti bytí, mohl Bůh stvořit svět již hotový. Bůh ale podle Teilharda tvoří proto, aby umožnil tvořit. $\mathrm{V}$ tom spočívá božský dar bytí. Jinak řečeno: Boží svoboda se projevuje především tím, že umožňuje svobodu - samoorganizaci všech stvořených bytostí. To je hlavní myšlenka, která jako červená nit prochází všemi Teilhardovými texty, ale explicitně formulovaná je pouze na několika málo místech. Poprvé, jak už je pravidlem, v deníku z první světové války, a to v podobě hesla: „Bůh tvoří věci tak, že se samy tvoří“ (Dieu fait se faire les choses). ${ }^{46} \mathrm{~V}$ jednom pozdějším textu je myšlenka upřesněna:

„Stvoření evolučního typu (Bůh tvoří věci tak, že se samy tvoří) bylo po dlouhou dobu považováno nejlepšími mysliteli za nejkrásnější představitelný způsob, jakým může Bůh působit ve vesmíru."47

Pozoruhodná je Teilhardova domněnka, že tato myšlenka byla už vždy přítomná v křest'anské tradici. Zda je to opravdu tak, nechám na posouzení historikům myšlení.

V rámci Teilhardovy teorie je tedy třeba tvrdit, že pléroma není statická záležitost, plnost bytí zahrnuje také cestu k němu a zdá se, že bez této cesty není vůbec konečná plnost myslitelná. Skutečným cílem stvoření, tedy tím, o co Bohu jde, důvodem proč vůbec tvoří, je to, aby umožnil tvořit i jiným bytostem, než je on sám. To je založeno na premise, že vyšší hodnotu má komplexita, tedy „dílo“, které si bytost vytvoří podle svých vlastních záměrů a nápadů, než dílo, jehož podoba byla nějakým způsobem nařízena. Tato premisa může být samozřejmě zpochybněna, ale zde ji konstatuji jako apriorní, byt' implicitní tvrzení Teilhardovy teorie. Zdá se, že mezi všemi Teilhardovými interprety je to hlavně Edward Vacek, který Teilharda v tomto ohledu plně pochopil. „Vůle Boží není předem daný plán, který má být objeven, ale spíše plán, který má být spolutvořen skrze uplatnění našeho vlastního rozumu a srdce.“48

\footnotetext{
${ }^{46}$ Teilhard (1975, s. 313).

${ }^{47}$ Teilhard (1957, s. 217).

${ }^{48}$ Vacek (2014, s. 159).
} 
Pléroma lze snad přirovnat k uměleckému dílu, jehož autorem je Bůh, např. k jakési velké mozaice bytí, ve které je ale každý z použitých kamínků svobodným dílem konkrétní stvořené bytosti, přičemž závěrečné uspořádání těchto prvků je necháno na Bohu. Zjednodušeně řečeno: Skutečná plnost bytí spočívá v tom, že si každá bytost sama určí, co v pléromatu chce mít, a Bůh dokáže každý příspěvek každé bytosti harmonicky uspořádat a zasadit do celku všech př́íspěvků ostatních. Toto uspořádávání výsledků (či náprava selhání) samoorganizace probíhá v průběhu evoluce neustále a jedním z důležitých nástrojů $\mathrm{k}$ němu je na úrovni noosféry podle Teilharda modlitba. Proto i výše zmíněný osamělý mnich žije plnohodnotný život, pokud své modlitby obětuje za harmonizaci vesmíru nebo jí jimi přímo napomáhá.

Synonymem pro tvoření je jednoznačně svoboda a samouspořádání. Cílem stvoření je proto poskytnout stvořeným bytostem možnost, aby si mohly svá „díla“, tedy všechny typy komplexních systémů, vytvářet samy, a to pokud možno hned od počátku stvoření. Tato aktivita, nazývaná také spontaneita, má různé stupně a v průběhu evoluce se nárůstem komplexity zintenzivňuje, přičemž pléroma je vyjádření pro její výsledek a završení. To je také hlavní smysl, v němž Teilhard používá termín ortogeneze. „Podstatou je jediná probíhající událost: velká ortogeneze všeho živého směrem k větší imanentní spontánnosti. “49 Elementární pravidla (zákony evoluce, např. Zákon diferencující jednoty) jsou dána od počátku, postupně ale narůstá schopnost kreativně s nimi zacházet. Evoluční pravidla a formy jsou ve své podstatě primárně určeny k tomu, aby umožnily tvořivost, nikoli omezovaly. Na úrovni geosféry je základní tvưrčí formou a „prostorem pravidel“ gravitační síla. Ta přitahuje hmotu do jednoho prostoru, „omezuje“ ji na jedno místo, ale právě tím vytváří pole pro navazování jakýchkoli vztahů a rozrůzňování takto centrovaných systémů. Vesmír bez gravitační síly by zůstal mrtvým prostorem rozptýlených prvotních částic, v němž by se nikdy neuskutečnila žádná vyšší syntéza. Formy biosféry jsou mnohem komplikovanější, ale v základě sestávají ze sady „pravidel života“, která jsou velmi podobná pro všechny živé bytosti, ale umožňují nekonečné varianty životních projevů. Tedy i zde je primární funkcí pravidel umožňovat variabilitu života, nikoli omezovat.

Nutným předpokladem dosažení plnosti bytí je objevení se bytosti, která bude moci vzít vývojový proces do vlastních rukou, tedy bude tvořit v nejsilnějším slova smyslu, což znamená pravidla nejen kreativně používat, ale také měnit a vytvářet nová právě tím se lidský druh nadaný sebevědomím liší od ostatních evolučních bytostí. Formy, které existují na úrovni noosféry, sestávají téměř výlučně ze soustavy uměle vytvořených pravidel, kam patří nejen zákony či morální pravidla, ale také pravidla nutná k různým typům tvorby, od řemesel po umění. Jako př́klad lze uvést pravidla jazyka, gramatiku a syntax, která jsou podmínkou vytvoření smysluplné věty (což je také druh vazby, spojení), ale přitom nijak nenařizují, co má být jejím obsahem. Jak

${ }^{49}$ Teilhard (1990, s. 128). 
bude evoluce pokračovat dál, závisí na tom, zda formy vytvářené člověkem budou komplexitu společnosti i jedince rozšiřovat či umenšovat.

\section{Závěr}

Jaké obecné kritérium z toho lze získat pro posouzení, zda komplexita jedince roste? Za prvé z hlediska jednoty: Různé složky duše mohou jednat jako jeden celek pouze tehdy, když jsou podřízeny společnému cíli ve smyslu určitého osobního ideálu. Řečeno metaforicky s Teilhardem: „Nech ve svatyni stát jen jeden oltáŕ.“50 Pro skutečně centrované jednání se nesmí stát, že duše bude sledovat více cílů a jeden z nich bude využívat zdroje na úkor druhého, což se týká i takových zdrojů, jako je čas. U každé činnosti, byt' zdánlivě podružné, by si člověk měl být vědom toho, jak se vztahuje $\mathrm{k}$ vytčenému cíli. Cíl se samozřejmě může v průběhu života měnit - v samoorganizující se evoluci má velkou cenu také schopnost flexibility, přičemž nelze poskytnout obecný návod, kdy vytrvat na zvolené cestě a kdy její cíl změnit. Hlavním kritériem je subjektivně pocitovaná intenzita bytí, tedy maximální využití schopností a zdrojů, které má konkrétní jedinec k dispozici k vytváření jednoho díla.

Individuální cíl by dále měl napomáhat naplnění obecného cíle celé evoluce. Bylo řečeno, že v Teilhardově teorii je obecným cílem, aby každá bytost mohla do konečné plnosti bytí přinést svůj vlastní jedinečný prríspěvek. Z hlediska různorodosti to znamená, že cíl, který následuje jednotlivec, by měl umožnit, aby co nejvíce jednotlivců nacházejících se v jeho vztahové síti, v jeho životním prostoru, si mohlo svobodně zvolit svůj cíl a svůj příspěvek celku. A to právě za pomoci zdroje, který svou činností posílá do celé sítě $\mathrm{k}$ dalším transformacím. Tímto se také jedinec stává „obrazem Božím“, centrem aktivně umožňujícím svobodu svého okolí. Žádné jiné kritérium než toto negativní nelze uvést, protože to by bylo v rozporu s hodnotou svobodného tvoření - nejvyšší hodnotou vesmíru.

Objektivní kritérium komplexity by tedy spočívalo v tom, kolik různorodých entit či spíše různorodých svobodně zvolených rolí může společně koexistovat v systému, který sdílí a transformuje společné zdroje. To také znamená, že komplexnější je ten systém, který umožňuje větší míru sebeurčení svých částí pod společnými pravidly.

Dalo by se namítnout, že to není nic úplně převratného. Jsou zde ale zajímavé aspekty, které nabízejí různé možnosti zkoumání. Pozoruhodná je zaprvé úloha forem a pravidel v Teilhardově teorii, především nezbytnost pravidel pro jakýkoli typ tvoření, ${ }^{51}$

\footnotetext{
${ }^{50}$ Teilhard (1965, s. 21).

${ }^{51}$ V současné filozofii se tématem zabývá např. R. Brandom (in: Perspectives on Pragmatism, kap. XI. Discursive Practise, s. 146-152). Teilhardovo chápání pravidel a cílů je inspirováno
} 
včetně „tvoření“ společenského, týkajícího se uspořádání společnosti. Společná forma celku je podle Teilharda nutným předpokladem rozrůznění členů tohoto celku a pouze správná pravidla umožňují sebeurčení - různé typy tvorby na základě týchž obecných forem. Teilhardovy úvahy o totalitních systémech a jejich hlavním problému, zestejňování a potlačování sebeurčení, jsou příkladem těchto úvah.

Důležité mi na Teilhardově teorii připadá, kromě zásadního důrazu na jednotu $\mathrm{v}$ různosti, také filozofické (a teologické) zdůvodnění celé koncepce. Jak bylo řečeno, považuje Teilhard za hlavní ,,pohon“ evoluce soutěž o omezené zdroje - používá spíše slovo hra než soutěž: „V té velké hře jsme sami hráči a zároveň i kartami a sázkou. “52 Samoregulující aspekt evoluce je přitom poměrně „drsný“: Dokud se lidé nenaučí využívat omezené zdroje a tvořit nové takovým způsobem, že tyto zdroje budou umožňovat sebeurčení a růst komplexity všech zúčastněných, to znamená doslova celého druhu homo sapiens, tak se budou špatně vytvořené celky rozpadat často za značného násilí, utrpení, destrukce a uvolnění obrovských ničivých energií. Přičemž bude toto utrpení zasahovat možná nejvíce ty, kdo jsou spíše obětmi než původci špatného využívání zdrojů. To je určitá nekompromisní a z lidského pohledu nespravedlivá mezilidská solidarita $\mathrm{v}$ jádru samoregulace, kterou Teilhard chápe jako evoluční alternativu tzv. „,ědičného hříchu“.

Občasná změna formy, aby byl zajištěn další růst, tj. možnost přibírat nové nebo kvalitativně odlišné části, je nutností také u správně utvořených celků, ale transformace nemusí být vždy provázena násilím, nenávistí nebo umenšením stávajícího životního prostoru. Teilhard opakovaně tvrdí, že lidstvo se nakonec sjednotí a evoluce dospěje svého završení, ale jak dramatická cesta to bude a co se nakonec objeví ve výsledné podobě, záleží na každém jedinci.

Zajímavé je pokusit se v rámci této koncepce zdůvodnit, proč vlastně musí nutně dojít ke konečnému sjednocení. Důvodem je patrně zmíněná touha po plnějším bytí vrozená každé bytosti. Neefektivní zacházení se zdroji, tedy takové, které neumožňuje samoorganizaci všech zúčastněných a především stálý růst, nakonec nemůže uspokojit právě tuto touhu stále více být. Např. hromadění nějakého zdroje, typicky peněz, není v posledku něco, co by mohlo touhu lidské duše po neustálém růstu uspokojit, protože tento zdroj nebude nikdy bezpečný před zkázou.

Důvodem, proč se tolik lidí soustřed'uje na tyto neefektivní činnosti, není podle Teilharda to, že by byli morálně zkažení, ale že mají strach z nedostatku - považují bytí za „nedostatkové zboží“ a neznají jiné zdroje. Bojí se také náročných transformací, které jsou občas s růstem spojeny a jejichž výsledek nemůže nikdy být znám předem,

patrně pragmatismem W. Jamese, v Brandomově knize lze nalézt jeden z možných způsobů, jak Teilhardovo pojetí rozpracovat.

52 Teilhard (1990, s. 192). 
ale tím se vzdávají aspektu bytí, který je možná nejdůležitější: Skutečná moc či síla (puissance) pramení právě ze schopnosti čas od času projít radikální změnou (tzn. proměnou formy duše, aby mohla dále růst). Strach, jehož následkem je taedium vitae nebo jednoduše nuda, jsou podle Teilhardova pojetí hlavní překážkou pokračování evoluce. Podobně je to $\mathrm{v}$ případě zneužití moci: Skutečně mocný je ten, kdo umí svou autoritou zaštítit formu celku, která umožňuje sebeurčení, a rozdává ze svých přebytků. Kdo k výkonu autority potřebuje násilí a zdroje hromadí na úkor jiných, jedná ze strachu.

Duši v posledku uspokojí pouze využívání a transformace zdroje, který umožňuje stálý růst a je nezničitelný, tzn. jeho transformace se nějak odrazí v nesmrtelném jádru duše. To jsou podle Teilharda pouze tři energie, na jejichž zvládání by se mělo lidstvo zaměřit: Láska, víra a rozšiřrování vědomí. Mnoho textů věnoval Teilhard např. problému kultivace náboženských ideálů, založených na energii víry, kterou ale spojuje také s touhou po objevování nového a tím také s vědeckým výzkumem. Je např́iklad zcela jisté, že žádné zákazy neodradí lidského ducha od výzkumu a zkoušení nových věcí. Výzkum proto nelze zakazovat, pouze regulovat pravidly, která se musí otestovat metodou pokus - omyl. „Pochopme konečně, že nic, absolutně nic, nezabrání člověku dojít ve všech směrech [...] až na samý kraj jeho schopnosti výzkumu a vynalézání.“53 Podobně s uspořádáním společnosti: Totality byly v určitém smyslu nutné, protože pouze vyzkoušením ideálu v praxi je možné zjistit, zda bude nebo nebude fungovat.

Z hlediska teologického je důležité, že co se týká vztahu Bůh - člověk, je zde důraz hlavně na aktivitu, překonání strachu, zodpovědnost za okolí, schopnost riskovat a tvořit. Člověk je nejdůležitějším hráčem v Božské hře, která má sice drsná pravidla, ale zato umožňuje zajít až do krajností intenzity bytí. Teilhardovo dílo má za cíl ukázat, že člověk může s Bohem na tvoření aktivně spolupracovat a že také Bůh se v podobě svého syna - Ježíše Krista - na evoluci podílí včetně osobní účasti na utrpení. Díky tomu také může nabídnout účinnou pomoc z každého ztroskotání. To jsou ovšem témata, se kterými je nejlepší seznámit se prřímo četbou Teilhardových textů. Cílem článku bylo vyjasnit pojem komplexity, a tím čtení těchto textů usnadnit.

\section{Seznam použité literatury}

Berrien, K. F. (1968): General and Social Systems. Rutgers University Press, New Brunswick.

D'Ouince, R. (1970): Un prophète en procès: Teilhard de Chardin et l'avenir de la pensée chrétienne. Aubier-Montaigne, Paris.

\footnotetext{
${ }^{53}$ Teilhard (1956, s. 351).
} 
Gleick, J. (2011): The Information. Vintage Books, New York.

Havel, I. (1995): „Scale Dimensions in Nature.“ International Journal of General Systems 23 (2): 303-332.

Heylighen, F (1996): „What is Complexity?“ Principia Cybernetica Web. [online] Dostupné z: 〈http://pespmc1.vub.ac.be/complexi.html>

Jirousová, F. (2015): Teilhard's de Chardin's Theory of Spiritual Evolution: Teilhard Studies Number 70, Spring 2015. American Teilhard Association, New York.

Johnson, N. (2009): Simply Complexity: A Clear Guide to Complexity Theory. Oneworld Publications, Oxford.

O'Connell, R. (1982): Teilhard's Vision of the Past. Fordham University Press, New York.

O’Manique, J. (1969): Energy in Evolution. Humanities Press, New York.

Salmon, J. (2010): „Teilhard's Science.“ In Rediscovering Teilhard's Fire, ed. K. Duffy, Saint Joseph's University Press, Philadelphia, 2010, s. 175-186.

Teilhard de Chardin, P. (1955): Le Phénomène Humain. Seuil, Paris.

Teilhard de Chardin, P. (1956): L'Apparition de l'Homme. Seuil, Paris.

Teilhard de Chardin, P. (1957) : La vision du passé. Seuil, Paris.

Teilhard de Chardin, P. (1959): L'Avenir de l'Homme. Seuil, Paris.

Teilhard de Chardin, P. (1962): L'Énergie Humain. Seuil, Paris.

Teilhard de Chardin, P. (1963): L'Activation de l'Énergie. Seuil, Paris.

Teilhard de Chardin, P. (1965): Écrits du temps de la guerre. Seuil, Paris.

Teilhard de Chardin, P. (1965b): Science et Christ. Seuil, Paris.

Teilhard de Chardin, P. (1970): Chut' žít. Vyšehrad, Praha.

Teilhard de Chardin, P. (1973): Les directions de l'avenir. Seuil, Paris.

Teilhard de Chardin, P. (1975): Journal 26 août 1915 - 4 janvier 1919. Fayard, Paris.

Teilhard de Chardin, P. (1988): Lettres inédites: Lettres à l'abbé Gaudefroy et à l'abbé Breuil. Le Rocher, Monaco.

Teilhard de Chardin, P. (1990): Vesmír a lidstvo. Vyšehrad, Praha.

Teilhard de Chardin, P. (1993): Místo člověka v prírodě. Svoboda-Libertas, Praha.

Vacek, E. (2014): „An Evolving Christian Morality: Eppur si muove.“ In From Teilhard to Omega: Co-creating an Unfinished Universe, ed. I. Delio, Orbis Books, New York, 2014, s. 152-165.

Viney, D. W. (2010): „Teilhard: Le Philosophe malgré l'Église.“ In Rediscovering Teilhard's Fire, ed. K. Duffy, Saint Joseph's University Press, Philadelphia, 2010, s. 69-88. 
Walter, J. (1969): „Complexité - Conscience, aujourd'hui.“ Études Teilhardiennes 1969/2 